\title{
Judean Royalty and Professionals in Babylon
}

\subsection{Introduction}

According to 2 Kings 24, Nebuchadnezzar II deported King Jehoiachin, members of the Judean upper class, and craftsmen to Babylonia after the conquest of Jerusalem in his eighth regnal year. ${ }^{345}$ The selective deportation of ruling elites and professionals was a common practice in the Neo-Assyrian period, ${ }^{346}$ and a group of administrative texts from Babylon show that the Babylonian Empire exercised a similar policy. These texts, the only surviving remnants of the state archives of Babylonia, record the distribution of oil rations to people of Babylonian and foreign origin around the thirteenth year of Nebuchadnezzar. King Jehoiachin, Judean princes, and other people of Judean origin are also attested on these lists, less than ten years after the deportations from Jerusalem in 597. Before the publication of the texts from Yāhūdu and its surroundings, documents from the Palace Archive of Nebuchadnezzar II (from now on, the 'Palace Archive') were undoubtedly the best-known cuneiform source for the study of Judeans in Babylonia. The reason for their fame, especially among biblical scholars, is obvious: the texts not only corroborate Jehoiachin's exile in Babylon, but their contents can also be compared with the account of his amnesty in 2 Kgs 25:27-30.

In this chapter, I study the Palace Archive and its information on immigrants in Babylon. I begin by introducing the archive, its archaeological context, and its publication history. Second, I move on to analyse the texts, focusing on the socio-economic status of Judeans and other foreigners in Babylon. Finally, I discuss the texts in relation to the account of Jehoiachin's amnesty in 2 Kings 25 .

\subsection{German Excavations at Babylon}

A German excavation team led by Robert Koldewey conducted the first thorough archaeological excavations at Babylon in 1899-1917. ${ }^{347}$ Because of the

\footnotetext{
345 According to a Babylonian chronicle, Jerusalem fell in the twelfth month of Nebuchadnezzar's seventh year, in spring 597. See Section 1.2.3.

346 Oded 1979, 22-23, 44, 48-59.

347 The following summary of the German excavations is based on the information in Pedersén 1998, 183-191; 2005a, 1-16, 109; 2005b, 267. Pedersén 2005a is not only a painstaking
} 
high level of the water table, the excavators had difficulties in reaching beyond the Neo-Babylonian and Persian strata, which are thus studied better than the earlier periods. The excavated area was primarily located in the palace and temple districts of the ancient city, but it also included the residential area of Merkes. The results of the excavations were well documented, compared to the archaeological practices of the early twentieth century. Almost 4,00o photographs provide valuable information on the excavations and on many objects that can no longer be located in museum collections.

The careful documentation of the German excavations turned out to be valuable, because many of the findings have become inaccessible during years of political turmoil in the Middle East. When the excavations started in 1899, the ruins of ancient Babylon lay within the borders of the Ottoman Empire, and the archaeological findings were supposed to be divided between Istanbul and Berlin. However, only a small number of items were delivered to the Istanbul Archaeological Museum before the First World War dramatically changed the political landscape of the Middle East. The excavation team was evacuated in 1917 when the Allied troops approached Babylon, and the findings were left in the excavation house until 1926. The majority of the items remained safe, but some of the most precious finds were looted and sold on the antiquities market. The Vorderasiatisches Museum in Berlin and the Iraq Museum in Baghdad divided the remaining items in 1926.

The discovery of the Ishtar Gate and its reconstruction in Berlin made Koldewey's excavations famous, but the other finds are poorly studied and published. Out of circa 5,200 tablets discovered in Babylon, 2,300 are in Berlin, 130 in Istanbul, and several dozen in museums and private collections around the world. Consequently, almost 3,00o tablets should be located in the Iraq Museum, but the war in Iraq prevented Olof Pedersén from inventorying these tablets in the early twenty-first century. Approximately 2,500 tablets can be located in museums and private collections, and when the excavation photographs are taken into account, there is some information on the contents of 4,067 tablets. Only six per cent of the tablets are published so far. ${ }^{348}$ Pedersén and Joachim Marzahn intend to publish the remnants of the Palace Archive, and a major publication project of the Babylon tablets in Berlin is planned. ${ }^{349}$

inventory of the discovered tablets but also an excellent overview of the excavations with further bibliography.

348 Pedersén 2005a, 1-13, 305.

349 Pedersén 2009, 195; personal communication with Pedersén in July 2013. 
The South Palace (Südburg) was the older of two huge royal palaces which Nebuchadnezzar II built in Babylon between the Processional Way and the Euphrates. Koldewey's team excavated the South Palace thoroughly, and its architectural design around five successive courtyards is well known. The eastern part of the building housed the offices and workshops of palace personnel, whereas the central part was dominated by the main courtyard and throne room. Living quarters were located in the west end of the palace. ${ }^{350}$ The northeast corner of the administrative premises was architecturally different from the rest of the palace. It was a vaulted structure that, according to Koldewey, might have been the foundation of the Hanging Gardens of Babylon. It may indeed have supported some heavy structure, and the foundations of the vaults contain a number of chambers that could have been used as storage rooms or a prison. ${ }^{351}$ When Koldewey's team excavated the vaulted structure, they found a group of circa 300 Neo-Babylonian tablets (archival group N1 in Pedersén 2005a), predominantly located in the vicinity of a staircase leading to the vaulted structure. These administrative texts had probably fallen there from an upper floor when the building was destroyed. Pedersén has been able to identify 303 tablets belonging to this group. ${ }^{352}$

Two smaller groups of tablets with similar contents were found outside the South Palace near the Ishtar Gate (N2, 25 tablets) and on the south side of the main entrance to the palace $\left(\mathrm{N}_{3}, 18\right.$ tablets). Tablets of group $\mathrm{N}_{2}$ were found deep below the floor level of the Processional Way and the Ishtar Gate, which means that they had already been discarded before the construction works during Nebuchadnezzar's reign. Because the excavation notes do not describe the find-spot of group $\mathrm{N}_{3}$ but only locate it in the sector Kasr $25 \mathrm{v}$, it cannot be confirmed whether these tablets were found inside the palace or just outside its walls. A number of fragmentary tablets were unearthed on the north side of the main entrance, but their contents and possible connections with the other three groups remain largely unclear. Almost all tablets in the three groups were written during the reign of Nebuchadnezzar in 601-577 BCE. The tablets from the entrance of the palace are the earliest (3-13 Nbk), followed by the tablets discovered at the Ishtar Gate (8-12 Nbk). The tablets from the vaulted structure

350 Van De Mieroop 2003, 268; Miglus 2004; Pedersén 2005a, 109-111; Jursa 2010b, 69-72.

$35^{1}$ Koldewey 1969, 38-64; Pedersén 2005a, 111-112. Koldewey (1969, 48) suggests that the chambers functioned as storage rooms; Pedersén (2005a, 112) leaves the question open. According to Jursa (2010b, 72 ), the eastern, administrative wing of the palace was a probable location for a prison.

Pedersén 2005a, 112-113. 
are the latest, dated predominantly in $10-28 \mathrm{Nbk}$ with the exception of a tablet dated in the fifteenth year of Šamaš-šum-ukīn $\left(65^{2}\right.$ BCE) and another one dated in the thirty-fourth year of Nebuchadnezzar (571 ВCE). ${ }^{353}$

In addition to the text groups discussed above, no other Neo-Babylonian archives were found in the North and South Palaces of Babylon. Accordingly, the administrative tablets in the three groups comprise the only surviving part of the documentation that the Neo-Babylonian state kept in the capital of the empire. When one considers the size of the royal archives unearthed in the Assyrian capital of Nineveh, it is clear that the Babylonian royal archives must have been impressive as well. ${ }^{354}$ Even though a significant part of the archives were probably written in Aramaic on perishable materials, the surviving tablets were hardly the only ones recorded on clay. ${ }^{355}$ It remains unclear why nothing else was found during the thorough excavation of the palace area.

Out of these 346 tablets, only 80 are located in museum collections. An additional 65 or so are preserved as photographs. The excavation journal briefly describes each of the 346 tablets. No more than 13 tablets are fully or partially published or their contents discussed in research literature. ${ }^{356}$ The tablets of group $\mathrm{N}_{1}$ are administrative documents recording the delivery of commodities to be stored and processed in Babylon, as well as their eventual distribution to people of Babylonian and foreign origin. Several different officials administered this process, among them courtiers ( $\check{s} a$ rēšs šarri), scribes, measurers, and counting officials. ${ }^{357}$ The tablets of groups $\mathrm{N}_{2}$ and $\mathrm{N}_{3}$ resemble those of the main group $\mathrm{N}_{1}$ and record the same process of delivery and distribution. As the systems of record-keeping differ somewhat between the three groups, they may originally have belonged to separate archival units. ${ }^{358}$ For the sake of convenience, I refer to these three groups collectively as 'the Palace Archive'.

The majority of the texts pertain to barley and dates. ${ }^{359}$ The quantities of delivered barley and dates are so large that they could not have been consumed by the personnel of the palace, and significant amounts must have been

353 Pedersén 2005a, 113, 128, 130.

354 On the royal archives from Nineveh, see Parpola 1986; Pedersén 1998, 158-165; Reade 2000.

355 See Fales 2007b; Jursa 2014b, 97-101; Radner 2014b, 83-86 on the role of Aramaic in the Babylonian and Assyrian state administration.

356 Pedersén 2005a, 113, 128-132; Jursa 2007c. Pedersén was able to locate 71 tablets in museum collections, and he is aware of nine tablets which are published or discussed. Michael Jursa identified an additional nine texts in museum collections, four of which are published.

357 Pedersén 2005a, 113-118. See also Waerzeggers (forthcoming a).

358 Pedersén 2005a, 128, 130.

359 Pedersén 2005a, 114-116. 
delivered elsewhere ${ }^{360} \mathrm{~A}$ few texts pertain to the delivery of emmer, flour, and sesame. In general, barley was transported to storehouses, but dates were often delivered to brewers for processing. ${ }^{361}$ Some of the barley was later ground into flour by people who were dependent on the palace. ${ }^{362}$ In addition to accounts of delivery and processing, the Palace Archive records the distribution of foodstuffs to people who worked for or were otherwise dependent on the palace. ${ }^{363}$ The texts reflect a real ration system, by means of which food was distributed to cover the basic needs of the palace personnel. This is different from the temple economy, in which payments in barley or dates often functioned as cash which could be exchanged for other products. ${ }^{364}$

A number of long lists record the distribution of sesame oil as rations to people of Babylonian and foreign origin, but also for the maintenance of wooden and metallic objects. ${ }^{365}$ Some oil was even sent to graves, probably for sacrifices. ${ }^{366}$ Four of the ration lists were partially published by Ernst F. Weidner in 1939, ${ }^{367}$ and Pedersén has summarised the contents of some unpublished tablets. ${ }^{368}$ Transliterations of the texts published by Weidner are available at CTIJ. The date has been preserved only in one document, which was drafted in the thirteenth year of Nebuchadnezzar II (591 BCE). ${ }^{369}$ Some of the recipients, such as shipbuilders, probably did not live in the palace; only

\footnotetext{
36o Jursa 2010b, 76 .

361 Pedersén 2005a, 114-117.

362 Grain was delivered to a prison for grinding (Jursa 2010b, 72). The recipients of grain included, among others, women and prisoners of war, who probably ground it as well (on the recipients, see Pedersén 2005a, 116). Grinding of flour was typically the task of women and, in an institutional context, forced labour. See Bongenaar 1997, 113, 118-120; Kleber 2005, 293-294, 317-318.
}

363 Pedersén 2005a, 116-118.

364 Jursa 2010b, 76. In general, ration systems are well-attested in the ancient Near East. People of foreign origin were often among the recipients of rations in the capital cities of empires. For two examples, see the discussions on the Persepolis Fortification tablets in Aperghis 2000 and on the wine lists from Kalhu (Nimrud) in Kinnier Wilson 1972, esp. 1-6, 90-94.

365 Weidner 1939; Pedersén 2005b.

366 Weidner 1939, text A obv. 16, rev. 19; Jursa 2010b, 71.

367 Weidner 1939. Consequently, these documents are often referred to as the 'Weidner tablets'. I refer to these four tablets using the same letters as Weidner: A = Bab $28122=$ Pedersén 2005a no. 35; B = Bab 28178 + 28299a = Pedersén 2005a no. 91; C = Bab 28186 = Pedersén 2005a no. 99; $\mathrm{D}=$ Bab 28252 (erroneously given as 28232 by Weidner) = Pedersén 2005a no. 165 .

368 Pedersén 2005a, 117-127; 2005b.

369 The available information on preserved dates is somewhat contradictory. According to Pedersén 2005a, 117, the oil lists are dated to 11 and 13 Nbk, but his inventory of the tablets gives a date only for no. 91 (?-XII-13 Nbk). The date 13 Nbk is corroborated by Pedersén 
the administration was run there. ${ }^{370}$ The lists record oil rations of one or more consecutive months; the average oil ration was one $q \hat{u}$ (about one litre). Because the sum of individual oil rations is significantly smaller than the total sum at the end of the lists, Pedersén raises the possibility that the rations were given on a daily instead of a monthly basis. ${ }^{371}$ As a daily ration, however, one $q \hat{u}$ would be too generous; as a monthly ration it would be enough to cover the basic needs of an individual. In any case, the variation in the size of individual rations is large, which seems to indicate that oil was distributed according to the status of the recipients, who were perhaps responsible for its redistribution in their circles. ${ }^{372}$

A peculiar feature of the ration lists is the ethnic diversity of the recipients. The palace not only maintained people of Babylonian origin, as areas on the fringes of the empire, especially the Eastern Mediterranean coast, are well represented: oil rations were distributed to people from Tyre, Judah, Ashkelon, Egypt, Media, and Elam, to name but a few. Interestingly enough, these areas closely follow the borders of the Neo-Babylonian Empire during the reign of Nebuchadnezzar II. ${ }^{373}$ The large number of immigrants from the Levant reflects the Babylonian campaigns in the west, as described in the Babylonian chronicle on the early years of Nebuchadnezzar II. ${ }^{374}$ In the following, I first discuss the presence of foreign professionals in Babylon, and, second, the attestations of foreign royalty in the archive.

\subsection{Foreign Royalty and Professionals in Babylon}

The foreign origin of the people in the Palace Archive and the archaeological and textual evidence of the Babylonian campaigns in the Levant suggest that a large number of people arrived in Babylon as deportees in the early sixth century. The Babylonian chronicle on the early years of Nebuchadnezzar II $(A B C 5)$, the Hebrew Bible, and archaeological data from Ashkelon and Jerusalem shed light on the fate of the very same people who are later attested on the ration lists. ${ }^{375}$ Although the land-for-service sector in the Babylonian

2005b, 268 and Weidner 1939, 925 (but note that on page 927 Weidner assigns the date to text C instead of B).

See Jursa 2010b, 73; Pedersén 2005b, 270.

371 Pedersén 2005a, 117-118.

372 Weidner 1939, 927; Waerzeggers (forthcoming a).

373 Pedersén 2005b.

$374 A B C 5$.

375 Section 1.2. 
countryside absorbed large numbers of deportees, skilled professionals were also needed in the capital and employed as craftsmen, officials, and soldiers. At the same time, members of foreign royalty were held hostage at the palace to ensure the loyalty of their relatives who ruled over the vassal kingdoms of Babylonia. ${ }^{376}$

Both selective deportations of craftsmen and elite ${ }^{377}$ and the practice of holding royal hostages ${ }^{378}$ are well attested in the Neo-Assyrian sources. Royal inscriptions boast about the deportations of royal officials, craftsmen, soldiers, and agricultural workers, ${ }^{379}$ and the Nimrud Wine Lists refer to groups of foreign professionals who were maintained by the royal palace. ${ }^{380}$ Although some craftsmen or mercenaries may have migrated to Assyrian cities on a voluntary basis, deportations must have played a key role in the influx of foreign professionals. ${ }^{381}$ Hostages were taken from royal houses opposing the empire, including Egypt, the kingdoms in Syria, and the Aramean tribe of Hindāru in Babylonia. These people were held captive in the Assyrian capital to ensure the loyalty of family members who ruled in vassal kingdoms and to indoctrinate prospective rulers into the beliefs and values of the empire. ${ }^{382}$

The Palace Archive of Nebuchadnezzar II bears witness to the presence of foreign officials, soldiers, and craftsmen in Babylon. Courtiers ( ̌̌a rēš šarri) from Egypt, Ashkelon, Judah, and Elam worked in the palace, ${ }^{383}$ and numerous soldiers of foreign origin received rations from the royal storehouses. A small number of Egyptians guarded the boatyard (bit sapināti) and the administrative wing of the palace (bìt qīpūti). ${ }^{384}$ Moreover, 800 Elamites were employed as guards of the bit qīputti, and more than 200 Carian guards worked in the city as well. ${ }^{385}$ Not all of these men were necessarily prisoners of war. They also could have been hired troops, because Carian mercenaries are attested around the Eastern Mediterranean and ancient Near East. ${ }^{386}$ Likewise, messengers

\footnotetext{
376 On the living conditions of these people, see Section 2.5.

377 Oded 1979, 22-23, 41-59.

378 Zawadzki 1995; Radner 2012.

379 RINAP 3/1 22 i:31-35; RINAP 433 iii:14'-22'.

380 Kinnier Wilson 1972, 90-94.

381 On the (forced) migration of Arameans to Assyria, see Nissinen 2014, 273-276, 295-296.

382 Zawadzki 1995; Radner 2012.

383 A rev. 20; C rev. ii:22; Pedersén 2005b, 269. See also Jursa 2011b, 161.

384 Weidner 1939, 930. On bìt qīpüti, see Jursa 2010b, 71.

385 Pedersén 2005b, 270.

386 Pedersén 2005b, 271. On Carians, see Haider 1988, 153-223; Raaflaub 2004, 206-210; Zadok 2005; Waerzeggers 2006. Cf. the critical views in Fantalkin and Lytle 2016, who seem to be unaware of the Palace Archive and the Carians in Borsippa.
} 
from Ionia, Persia, Hume (Que), ${ }^{387}$ and Pirindu ${ }^{388}$ were maintained by the palace, but only visited there. ${ }^{389}$

Carpenters, sailors, and other specialists enjoyed royal maintenance as well. Carpenters (naggāru) from Arwad, Byblos, and Ionia are attested on the ration lists, and Ionian carpenters also worked at the boatyard. ${ }^{390}$ Boats and ships were operated by numerous sailors (malähu) from the Mediterranean coast and Tilmun. ${ }^{391}$ In the same vein, Sennacherib deported boatbuilders and sailors from the Eastern Mediterranean to Nineveh, ${ }^{392}$ which implies that their expertise was highly valued in Mesopotamia. Finally, foreign professionals were needed to entertain the king and his court in Babylon, as the presence of

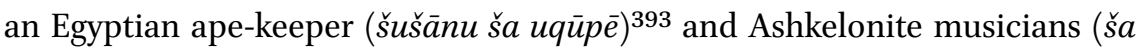
rēši nāru $)$ on the ration lists demonstrates. ${ }^{394}$

Some Judean professionals were brought to Babylon as well, which matches the information on selective deportation from Jerusalem in 2 Kings $24 .{ }^{395}$ In addition to King Jehoiachin and his sons, a number of Judean people are referred to on the ration lists. A certain Qanā-Yāma delivered oil rations to Jehoiachin's sons, ${ }^{396}$ which suggests that he was a servant or overseer of the Judean princes. ${ }^{397}$ A Judean sêpiru ${ }^{398}$ named [...]-Yāma delivered rations to a group of captives (hubtu) from Hume. ${ }^{399}$ Three other Judeans are mentioned by name: Samak-Yāma ${ }^{400}$ and Šalam-Yāma the gardener (nukaribbu ${ }^{401}$ bear Yahwistic names, and a certain Üru-Milki is explicitly described as Judean. ${ }^{402}$ Judean

387 The country of Que was located in the Cilician Plain. See Hawkins 2007.

388 Located in Cilicia. See Streck 2005.

389 A rev. 12-18; Pedersén 2005b, 270.

390 C rev. ii:13-15; D:16-18.

391 B rev. i:7-11; Pedersén 2005b, 270. The regions on the Eastern Mediterranean coast include Egypt, Ashkelon, Tyre, Mahazīnu, and Șapūnu. Mahazīnu and Șapūnu were perhaps located on the Mediterranean coast north of the Phoenician cities. See Zadok 1979b, 164-166.

392 RINAP 3/2 46:57-62.

393 A rev. 24.

394 C rev. ii:22-23; D:25-26; Weidner 1939, 928. See also Jursa 2011b, 161.

395 See Section 1.2.3.

396 C rev. ii:18; D:21.

397 Zadok 1979a, 38-39.

398 Sēpirus were not mere alphabetic scribes but officials who performed various administrative functions. See Stolper 1985, 22; Pearce 1999; Jursa 2012; Bloch 2018; and Section 5.3.2.

399 A rev. 8. On this text, see Bloch 2018, 224-230.

400 A obv. 28.

401 A obv. 31; rev. 22.

402 A obv. 11; rev. 13. The titles of Šalam-Yāma and Üru-Milki are broken on the obverse, but the same persons are probably referred to on both sides of the tablet. On the name Üru-Milki, 
courtiers (ša rēšs šarri) are attested among other royal officials of foreign origin (see above), and a group of eight Judeans are referred to several times on the ration lists. ${ }^{403}$

Royalty from three western kingdoms - Lydia, Ashkelon, and Judah - are


ferred to in A obv. $4 .{ }^{404}$ Weidner published the tablet on the basis of an excavation photo, and the dirt on the tablet prevented him from reading the other signs on the line; therefore, it remains unclear whether the former king of Lydia himself, his family members, or messengers resided in Babylon. The presence of the Lydian king in Babylon does not fit into the general historical picture very well, because Lydia retained its independence until the Persian conquest of Western Anatolia in the 540S BCE ${ }^{405}$ However, Babylonian military operations reached the borders of Lydia, ${ }^{406}$ and high Lydian officers or members of the royal family could have arrived in Babylon as deserters or prisoners of war. ${ }^{407}$ This argument is supported by the presence of other Lydians in Babylon, one of whom is called maqtu ('refugee, fugitive').408

Two sons of Aga? , the king of Ashkelon, are attested on the ration lists. ${ }^{409}$ The amount of oil they received, one $q \hat{u}$ for each of them, is the average ration in the Palace Archive. ${ }^{410}$ Aga ${ }^{2}$ himself is not attested on the lists, but the fate of Ashkelon in the late seventh century is well known. A Babylonian chronicle describes the events in the first year of the reign of Nebuchadnezzar II (604603 BCE): 'He (Nebuchadnezzar) went to Ashkelon(?) and captured it in the month of Kislimu. He took its king captive, plundered it, and [carried off] its booty. He turned the city into mounds and ruins and set off in the month of Šabāțu and [returned] to Baby[lon]'411 The name of the conquered city is partly

see Zadok 1988, 54; PNA 3/II, 1419-1420. Gad-il (A obv. 18) has a West Semitic name, but nothing suggests that he was of Judean origin; cf. Weidner 1939, 927; Zadok 1979a, 39. On the name, see PNA 1/II, 418 .

403 A obv. 26; rev. 28; B obv. ii:40.

404 See Weidner 1939, 934.

405 Briant 2002, 34-38. On the cuneiform evidence of this event, see Schaudig 2001, 24-25 n. 108.

406 Chronicle of Neriglissar ( $A B C$ 6:23-27); Nabonidus' 'King of Justice' inscription (Schaudig 2001 P2 v:20-21, see also pp. 579-580).

407 Compare to the case of Egyptians in Nineveh; see Radner 2012.

408 A obv. 22 (perhaps also 33); rev. 25; Weidner 1939, 934. Weidner (1939, 934) understands ba/ma-ak-tu as a title of an official (baktu), but CAD B, 35; CAD M/1, 254-255; and Wiseman 1985,83 understand it as a reference to maqtu ('refugee, fugitive').

4092 dumu.meš šá ${ }^{\mathrm{I} a} a-g a^{2}{ }^{2}$ lugal šá ${ }^{\text {kur }}$ iš-qil-lu-nu 1 sila. [àm] (B rev. i:6).

410 Pedersén 2005a, 117.

$411 \quad A B C$ 5: obv. 18-20. 
broken, but on the grounds of the remnants and clearly readable signs (-il-lu$n u$ ), the name should be restored as Ashkelon (iš-qí-il-lu-nu). ${ }^{412}$ This assumption is further supported by archaeological evidence, which shows that Ashkelon was destroyed in the late seventh century during the Babylonian campaigns in the Levant. ${ }^{413}$ It appears that the sons of the last king of Ashkelon were taken to Babylon as prisoners of war. Ashkelon lay in ruins and was rebuilt only in the Persian period, ${ }^{414}$ which suggests that there was no vassal king ruling over the city. Therefore, the well-being of the Ashkelonite princes in Babylon was not dependent on their relatives' loyalty to the Babylonian king. ${ }^{415}$

Despite the destruction of Ashkelon, some areas in the Levant were evidently turned into vassal states and ruled by local kings. The nature and extent of the Babylonian control and administration of the Levant is a debated topic, ${ }^{416}$ but the existence of vassal states finds support in the Hofkalender of Nebuchadnezzar II. The Hofkalender is a building inscription that commemorates the king's building works at the South Palace, but it also contains a list of dignitaries who contributed to the building project in one way or another. ${ }^{417} \mathrm{Be}-$ fore the list breaks at the end, kings of Tyre, Sidon, Arwad, Ashdod, Gaza, and two other kingdoms are mentioned ( col vii*:23'-29'). There is no reason to believe that they were held captive in Babylon, but they ruled vassal states in the Levant and participated in the building project by sending tributes to Babylon. ${ }^{418}$ This implies that these cities were not destroyed and abandoned in the late seventh century, but they still functioned as centres of royal power when the Hofkalender was written. ${ }^{419}$ As only the site of Ashdod has been excavated, it remains unclear how most of these vassal states and their capital cities were

412 For a discussion on restoring the name, see Fantalkin 2011, 87 n. 1; Stager 2011, 3 n. 2. Grayson (1975a, 100) is cautious about restoring the name as Ashkelon, but Glassner (2004, 228-229) reads 'Ashkelon' without expressing any doubts.

413 Stager 2011; Fantalkin 2011. For the full excavation reports, see Stager et al. (eds.) 2008, 2011.

414 Lipschits 2005, 41 n. 17 (but cf. 64 n. 98); Stager 2011, 11; Faust 2012, 200.

415 Cf. Weidner 1939, 928.

416 See, for example, Barstad 1996; Vanderhooft 1999, 61-114; Lipschits 2005; Faust 2012.

417 The inscription is edited in Da Riva 2013. See also Vanderhooft 1999, 92-98; Jursa 2010b, 67-68, 78-91.

418 Vanderhooft 1999, 97; Da Riva 2013, 204-205. Cf. Cogan and Tadmor 1988, 329; Katzenstein 1994, 46-47; Avishur and Heltzer 2007, 20.

419 The Hofkalender was written in the seventh year of Nebuchadnezzar (598-597 BCE) at the earliest. This year is mentioned in col. iv $: 25^{\prime}-31^{\prime}$, but it only refers to a delivery of commodities to storehouses, not to the year when the inscription was written (Da Riva 2013, 196, 227). 
affected by Egyptian and Babylonian military operations. ${ }^{420}$ Babylonian sources reveal that Tyre remained inhabited, although under the control of the Babylonian Empire. ${ }^{421}$

Although its name is not mentioned in the preserved sections of the Hofkalender, Judah was also turned into a vassal state in the late seventh century. ${ }^{422}$ After an unsuccessful revolt, the Babylonian troops conquered Jerusalem in 597 and deported King Jehoiachin to Babylon. Jehoiachin's uncle Zedekiah was set on the throne as the new vassal king in Jerusalem, but after a second unsuccessful revolt, Jerusalem was destroyed and Judah's existence as a vassal state came to an end, perhaps in 587 or 586 . The presence of King Jehoiachin and five Judean princes on a ration list from 591 shows that they were held hostage while Zedekiah was still ruling Judah as a vassal king. In addition to the list from 591, Jehoiachin is attested on three other ration lists from the Palace Archive:

A obv. 29: $[\ldots]^{\mathrm{I}} i a^{-}{ }^{2}-u$-gin lugal $[\ldots]$

B obv. ii:38: 1 bán $a-n a ~\left[{ }^{1} i a\right]^{2}$-gin lugal šá ${ }^{\mathrm{kur}} i a-[a-h u-d u]$

C obv. ii:10: 1 bán I ia-a-ú-ia(?)[...]

C rev. ii:17: 1 bán $a-n a$ I $i a-k u-u ́-k i-n u$ dumu lugal šá ia-ku-du

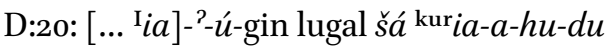

The standard formula is 'one sūtu for Jehoiachin, the king of Judah', but C rev. ii:17 is an interesting exception, 'one sütu for Jehoiachin, son of the king of Judah'.

The sons of the king of Judah are attested four times:

B obv. ii:39: $2^{1 / 2}$ sila $a-n a ~ 2[+3$ dumu.]meš lugal šá kur $i a-a-h u-d u[\ldots]$

C obv. ii:11: $2^{1 / 2}$ sila ana 5 dumu.meš [...]

C rev. ii:18: $2^{1 / 2}$ sila šá 5 dumu.meš šá lugal šá ia-ku-du ina šuII I $q a-n a-{ }^{2}-a-[m a]$

D:21: [... 5 dumu.meš šá lugal] šá kur ia-a-hu-du ina šu ${ }^{\mathrm{II}}$ I $q a-n a-a-m a$

The standard formula is ' $21 / 2$ qu for the five sons of the king of Judah from the hand of Qanā-Yāma'.

420 Aubet 2001, 60-69; Stern 2001, 412. Ashdod was certainly inhabited in the Persian period, but the situation in the seventh and sixth centuries is disputed. See Finkelstein and Singer-Avitz 2001, 2004; Ben-Shlomo 2003, 2005; Faust 2012, 31; Fantalkin 2014; Thareani 2016, 90-91.

421 Zawadzki 2015; van der Brugge and Kleber 2016.

422 For a more detailed discussion of these events and relevant sources, see Section 1.2. 
The oil rations given to Jehoiachin were large, being six times bigger than the average ration of one qu in the archive. ${ }^{423}$ As this amount would have been too much for his own personal needs, the rations were perhaps meant to be redistributed to his family members and other dependants. ${ }^{424}$ Jehoiachin's excessive rations may also imply that the Babylonians respected his royal status. ${ }^{425}$ This is corroborated by the fact that he also retained his royal title, even though he was taken to Babylon and actually it was Zedekiah who ruled the vassal state of Judah. Jehoiachin is once called 'the son of the king of Judah' on the ration lists, but this must be a scribal error. ${ }^{426}$ Weidner also raises the possibility that because the Babylonians held Zedekiah as the king of Judah, the same title was not used when referring to Jehoiachin. However, it is difficult to explain why this applies only to one instance on the ration lists.

Five sons of the king of Judah are regularly attested after Jehoiachin on the ration lists. Weidner wondered whether these people were Jehoiachin's sons or brothers. ${ }^{427}$ The first option is more plausible, ${ }^{428}$ as supported by the simple reasoning that if the king of Judah and the sons of the king of Judah are attested on two successive lines, the text naturally refers to a single king and his sons. ${ }^{429}$ Moreover, if Jehoiachin was eighteen years old when he was deported to Babylon in 597 (2 Kgs 24:8), he could easily have begot five sons by 591. This implies that some of his children were born in exile and that his living conditions in Babylon were good enough to allow him to beget and raise children.430 The Judean princes received a modest oil ration of half a qu each, only half of the rations given to the Ashkelonite princes. This is perhaps related to the young age of the Judean princes. A Judean man called Qanā-Yāma delivered the oil rations to the princes, and he was likely their servant.

423 Jehoiachin's rations were smaller than Weidner $(1939,927)$ suggests. One should read '1 bán' (CTIJ) instead of ‘1/2 (pi)' (Weidner 1939, 925-926). This becomes clear in C rev. ii:14, according to which $7^{1 / 2} q \hat{u}$ (1 bán $1^{1 / 2}$ sila) of oil was distributed to eight people, 1 qu for each, and half a $q \hat{u}$ was still to be delivered.

424 Weidner 1939, 927; Waerzeggers (forthcoming a).

425 Albertz 2003, 99.

426 Weidner 1939, 926. Pedersén 2005b, 269, writes that 'he [Jehoiachin] is sometimes referred to as king sometimes as prince'. It remains unclear whether Jehoiachin is also titled as a prince in the unpublished tablets.

427 Weidner 1939, 926-927. Gerhards 1998, 66, argues that the five princes were not Jehoiachin's sons.

428 See, for example, Albright 1942, 52-53; Oded 1995, 210; Albertz 2003, 102-103; Becking 2007, 181-182.

429 Observed already by Albright 1942, 53 .

430 Oded 1995, 210; Albertz 2003, 103. 


\subsection{Living Conditions in Babylon and Jehoiachin's Amnesty}

It is striking that such a diverse group of people originating from the border zones of the Babylonian Empire resided in Babylon in the early sixth century. Although some of these people, such as Carian mercenaries, may have migrated to the city voluntarily, the majority arrived in Babylon as deportees. They were maintained by the royal administration, but hardly all of them resided at the palace. Boatbuilders and some guards worked at the boatyard, and more probably lived there than at the South Palace. ${ }^{431}$ Courtiers and foreign messengers certainly spent more time at the palace than boatbuilders, but it still cannot be ascertained that they actually lived on the palace premises. The ration lists were found at the South Palace and its vicinity because the recipients were dependent on the palace and royal officials managed the inflow and distribution of the commodities. Therefore, their find-spot is related to their function and origin, not necessarily to the whereabouts of the people they referred to. ${ }^{432}$

The living conditions of the foreign recipients of oil were hardly uniform. The average monthly ration of one $q \hat{u}$ or one litre of oil was not particularly generous, but if other commodities were distributed in proportion to oil, the rations satisfied the basic needs of recipients. The size of the rations differed from one recipient to another, with King Jehoiachin, for instance, receiving twelve times more oil than his sons. This could be connected to their difference in status, and it is possible that recipients of large rations had to distribute the oil among their family members and other dependants. In addition to oil, barley and date beer were distributed to the foreigners, but meat and other more expensive commodities are not referred to in the Palace Archive. ${ }^{433}$ Courtiers and other palace personnel of upper rank certainly received meat rations as well, but this was apparently documented in a separate archive. ${ }^{434}$ Accordingly, even though foreign professionals and royalty were nourished well enough to do their work and reproduce, it remains unclear if their diet differed from that of the average Babylonian craftsman or farmer.

Even if the majority of foreign people did not reside at the palace, they were certainly supervised and their freedom was limited. However, the means to exercise control over foreigners were manifold. Mercenaries and messengers

\footnotetext{
431 See Jursa 2010b, 73.

432 Pedersén 2005b, 270; Waerzeggers (forthcoming a).

433 Distribution of barley is documented in the archive, and dates were delivered to brewers. Pedersén 2005a, 115-117.

434 Waerzeggers (forthcoming a). On rations, see also Waerzeggers 2006.
} 
from distant kingdoms were overseen, but they must have been free to leave the city when their service contract or diplomatic mission came to an end. At the other extreme, a prison (bit kiläni) is mentioned in the texts, ${ }^{435}$ but it is unlikely that foreign professionals were kept there, as incarceration was at odds with the productivity of craftsmen. Deported specialists certainly had reasons to resist their Babylonian overlords and attempt to escape, but economic dependence and administrative control were more useful bonds than incarceration. The ration lists and the administrative system related to them were effective control mechanisms as such: dependence on royal maintenance and the regular distribution of rations linked the recipients to the royal officials running the system. When scribes drafted the ration lists, they not only produced a record but also exercised control over the people listed on the tablets. ${ }^{436}$ Escape from Babylon without any travel funds was a huge risk for people who had been deported from their distant homelands in Iran or on the Mediterranean coast. Accordingly, the deportees could be supervised and their freedom severely limited even if they were not necessarily confined physically in a prison or sweatshop.

The previous discussion also outlines the parameters of the freedom and living conditions of Jehoiachin and other foreign royalty in Babylon. The incarceration of foreign royalty seems unlikely, because Jehoiachin apparently enjoyed family life in Babylon and received large rations. One should not be misguided by the fact that prison wardens are mentioned two lines below Jehoiachin and his sons on two ration lists. ${ }^{437}$ Although the more complete text $\mathrm{C}$ reads $4{ }^{\text {lúsag } u ́-s ̦ e-e r-t i-s ̌ u ́-n u ~(' f o u r ~ c o u r t i e r s, ~ t h e i r ~ p r i s o n ~ w a r d e n s '), ~ t h e ~ p o s-~}$ sessive suffix hardly refers to the Judean royalty. ${ }^{438}$ On the line between the Judean royalty and prison wardens, the texts mention wooden stools (giskit-tu$r a-n u)$ as recipients of oil rations. ${ }^{439}$ As this line clearly introduces a new topic, it is difficult to maintain that the prison wardens were responsible for guarding the Judean royalty or other people listed above.

Because Ashkelon and Lydia were probably not vassal kingdoms of the Babylonian Empire, the royalty from these kingdoms were not held in Babylon in order to ensure the loyalty of their relatives in a vassal state. They were not

\footnotetext{
435 Pedersén 2005a, 115-116; Jursa 2010b, 72.

436 See Waerzeggers 2015, 186-187.

437 C rev. ii:20; D:23.

438 Cf. Jursa 2000, 506-507. On the word usertu, see also CAD U-W, 285-286.

$439 \mathrm{C}$ rev. ii:19. Line 22 in text $\mathrm{D}$ is broken but is to be read similarly. The word should probably be read as kitturrānū ('stools', see CAD K, 476; Deller and Finkel 1984, 87-88), although CTIJ suggests reading it as gišs' $a t^{\prime}$ (КIT)-tu-ra-nu ('wagons', see CAD A/2, 510). In any case, the determinative giš leaves no doubt that the passage refers to wooden items.
} 
hostages per se, because their life and well-being was not dependent on the good behaviour of their family members back home in Ashkelon or Lydia. Their situation is reminiscent of Egyptian princes in Nineveh, who were taken captive in battle and perhaps sent back to Egypt only after Assyria conquered the region. ${ }^{440}$ Ashkelonite and possibly Lydian royalty were kept in Babylon for the same purpose, to serve the Babylonians if the political situation in their native country changed over time. The practice of sending vassal kings from Babylon to Tyre is also alluded to by Josephus, but this late account cannot be verified from any other source. ${ }^{441}$

The reason for keeping Jehoiachin and his sons in Babylon was partially the same, but, unlike the Ashkelonites, they were held hostage to ensure the loyalty of the vassal king in Jerusalem. This did not prevent Zedekiah from rebelling, but because the only datable ration list was drafted before his revolt, it remains uncertain if the hostages were killed or harmed as punishment. Jehoiachin's captivity in Babylon is also treated in 2 Kings, which ends in an optimistic account of his amnesty in the reign of Amēl-Marduk, or Evil-merodach, as the name is written in the Masoretic text:442

In the thirty-seventh year of the exile of King Jehoiachin of Judah, in the twelfth month, on the twenty-seventh day of the month, King Evilmerodach of Babylon, in the year that he began to reign, released King Jehoiachin of Judah from prison; he spoke kindly to him, and gave him a seat above the other seats of the kings who were with him in Babylon. So Jehoiachin put aside his prison clothes. Every day of his life he dined regularly in the king's presence. For his allowance, a regular allowance was given him by the king, a portion every day, as long as he lived. (2 Kgs $25: 27-30)^{443}$

The text depicts Jehoiachin's first thirty-seven years in Babylon as a hard time: he was confined in prison $\left(b y t k l^{2}\right)$, and his low status is further emphasised by a reference to his prison clothes $\left(b g d y k l^{2} w\right)$. However, his life changed drastically after the accession of Amēl-Marduk: he was released from prison and enjoyed his meals at the king's table until the end of his life. Interestingly, 2 Kings assumes that Jehoiachin was not the only foreign king held in Babylon. After

$440 \quad$ Radner 2012.

441 Josephus Ag. Ap. 1.21.

442 On the name, see Gerhards 1998, $5^{2}$ n. 2.

443 The same account is given in Jer 52:31-34. Unlike in many other parts of 2 Kgs $24-25$, there are no major textual problems in this passage (Person 1997, 90; Chan 2013, 567). 
his release, Jehoiachin was elevated to a higher status than the other kings. It is noteworthy that the text explicitly refers to Jehoiachin's regular allowance (' $r h t$ tmyd), which immediately reminds the modern reader of the ration lists in the Palace Archive.

The relationship between the biblical account of Jehoiachin's captivity and the information gleaned from the Palace Archive has been interpreted in different ways. On the one hand, some scholars have strong doubts about the historicity of Jehoiachin's amnesty, and they argue that the account primarily has an ideological and literary function. ${ }^{444}$ Even if one does not accept this view, it is obvious that the verses have a clear narrative function as the ending of the Book of Kings and the story of the kingdom of Judah. Whether or not the account intends to convey a message of hope - and if so, for what end - is a contested issue. ${ }^{445}$

On the other hand, it has been argued that the account in 2 Kgs 25:27-30 has some historical core, but the Palace Archive reflects a favourable treatment of Jehoiachin. This can lead to two different conclusions. First, the biblical account of Jehoiachin's imprisonment does not describe the situation at the time when the ration lists were written. Second, both the biblical account and the Palace Archive bear testimony to the leniency towards Jehoiachin. Rainer Albertz argues that Jehoiachin enjoyed good treatment for some time, but that he was punished for the revolt of Zedekiah or, more likely, for the murder of Gedaliah and imprisoned until the accession of Amēl-Marduk. ${ }^{446}$ According to Bustenay Oded and Bob Becking, Jehoiachin was held captive until he was released by Amēl-Marduk, although he was treated well and his living conditions were good, as reflected in the Palace Archive. ${ }^{447}$ Oded further argues that the word 'prison' should not 'be taken in the narrow sense' in this context. ${ }^{448}$ Becking suggests that the release of Jehoiachin was an act of amnesty right before the first akitu festival of Amēl-Marduk. ${ }^{449}$ Yitzhak Avishur and Michael Heltzer also understand Jehoiachin's captivity and living conditions in similar terms, speculating that his release was related to Amèl-Marduk's attempt to win the support of the well-organised community of Judean exiles. ${ }^{450} \mathrm{Jacob} \mathrm{L}$. Wright suggests that although Jehoiachin enjoyed royal maintenance already

\footnotetext{
444 See Barstad 1996, 28-29; Pakkala 2006, 451-452.

445 See the literature in Chan 2013, 567-568.

446 Albertz 2003, 102-104.

447 Oded 1995, 209-210; Becking 2007, 181-182.

448 Oded 1995, 210.

449 Becking 2007, 177-184.

$45^{\circ}$ Avishur and Heltzer 2007, esp. 21, 35-36.
} 
in the reign of Nebuchadnezzar, a late date for his release better fits the narrative 'sequence of defeat and restoration' in the last chapters of 2 Kings. ${ }^{451}$

As regards Jehoiachin's amnesty in the reign of Amēl-Marduk, Irving Finkel's article from 1999 has received surprisingly little attention. ${ }^{452} \mathrm{He}$ argues that, according to Babylonian and later Jewish traditions, Amēl-Marduk fell from grace and was imprisoned during the reign of his father Nebuchadnezzar II. Moreover, a medieval Jewish text suggests that Amēl-Marduk was imprisoned together with Jehoiachin, and once the crown prince was released and he ascended the throne, he also liberated Jehoiachin. Finkel's point of departure is an undated Late Babylonian literary text BM 40474 ('the Lament of Nabûšum-ukīn'), which records the lament of a distressed person. ${ }^{453}$ An exceptional feature of this text is that the name of the supposed author, Nabû-šum-ukinn, son of Nabû-kudurri-uṣur, is mentioned at the end of the tablet. Nabû-šumukīn laments his misfortunes in prison and prays to Marduk for help. Finkel argues that the father of this man was none other than King Nebuchadnezzar and that Nabû-šum-ukīn should be identified as crown prince Amēl-Marduk.

Finkel finds further support for his view in another Babylonian tablet and two Jewish texts. The Babylonian text in question is BM 34113, which is an undated, fragmentary literary text concerning Amēl-Marduk. ${ }^{454}$ The beginning of the obverse is partially readable, but the rest of the obverse is lost and the reverse is almost illegible. The poor condition of the tablet allows different interpretations. The beginning of the tablet undoubtedly refers to Nebuchadnezzar and Amēl-Marduk, and, according to Finkel, it describes how Amēl-Marduk is slandered and how he prays to Marduk for help. ${ }^{455}$ This interpretation is possible, but it is not more likely than Schaudig's reading, according to which the tablet gives a negative account of the reign of Amēl-Marduk and possibly depicts Nabonidus' piety in positive light. ${ }^{456}$ Furthermore, it should be noted

451 Wright 2011, 110-111 + n. 11 .

$45^{2}$ Finkel 1999. See Waerzeggers (forthcoming b).

453 The text is edited in Finkel 1999; Oshima 2011, 316-327. The tablet was found during Rassam's excavations and originates from Babylon or Borsippa. See Finkel 1999, 324; and the British Museum catalogue entry at http://www.britishmuseum.org/research/collection online/collection_object_details.aspx?objectId=327274\&partId=1\&searchText $=40474 \& p a$ ge $=1$.

454 Edited in Grayson 1975b, 87-92; Finkel 1999, 336 (only obverse); Schaudig 2001 P3. The tablet originates from the antiquities market. It may have been found in Babylon. See the British Museum catalogue entry at http://www.britishmuseum.org/research/collection online/collection_object_details.aspx?objectId=794748\&partId=1\&searchText=34113\&pa ge $=1$.

455 Finkel 1999, 337.

$45^{6}$ Schaudig 2001, 589. See also von Soden 1975, 284. 
that von Soden suggests that the fragment might join the 'King of Justice' inscription, ${ }^{457}$ in which case it would probably originate from the reign of Nabonidus. ${ }^{458}$ If this is correct, the text is hardly a reliable source for the study of historical events in the reign of Nebuchadnezzar or Amēl-Marduk.

Finally, two Jewish sources, Leviticus Rabbah (or Wayiqrah Rabbah) and the Chronicle of Jerahmeel, suggest that Nebuchadnezzar imprisoned AmēlMarduk before the latter ascended to the throne in Babylon. According to Leviticus Rabbah xviii: $2,{ }^{459}$ an early Midrash perhaps from the fifth century $\mathrm{CE},{ }^{460}$ the Babylonian elite raised Amēl-Marduk to the Babylonian throne during his father's absence of seven years. When Nebuchadnezzar returned to Babylon, he imprisoned his son because of the coup d'état. According to the Midrash itself, this account has been influenced by the tradition of Nebuchadnezzar's absence from Babylon, which can be found in Daniel 4. It is easy to see how the narrative of Amēl-Marduk's coup and imprisonment developed from the existing tradition.

The Chronicle of Jerahmeel refers to a Medieval Hebrew manuscript held at the Bodleian library. ${ }^{461}$ It is a collection of Jewish writings apparently compiled by a certain Eleazar ben Asher ha-Levi, who claims to have used the texts of Jerahmeel ben Solomon as one of his sources. Little is known about Eleazar and Jerahmeel, but the traditions used in the Chronicle appear to originate from numerous sources, including Midrashim and classical authors such as Strabo. According to the Chronicle of Jerahmeel, ${ }^{462}$ Amēl-Marduk was imprisoned because his brother slandered him. The brother ascended to the Babylonian throne and Amēl-Marduk was only released after the death of his brother. Amèl-Marduk had met Jehoiachin in prison, and when he started to reign after his brother, he also ended Jehoiachin's captivity.

Finkel's thesis is intriguing, and Leviticus Rabbah and the Chronicle of Jerahmeel seem to support his argument. However, both texts were written at least a thousand years after Amēl-Marduk's lifetime, and the narratives were obviously created on the basis of earlier literary motifs. As argued above, Leviticus Rabbah builds upon the traditions of Nebuchadnezzar's and Nabonidus' seven-year absence from Babylon. The Chronicle of Jerahmeel seems to be aware of the narrative in Leviticus Rabbah, as both of them share the motifs of

\footnotetext{
457 von Soden 1975, 284. See also Schaudig 2001, 589 .

$45^{8}$ See Schaudig 2001, 579-580, 589.

459 For an English translation, see Neusner 1986, 356.

46o Neusner 1986, xviii; Heinemann 2007.

461 Jacobson 1997, 239-250; David 2007. The Chronicle of Jerahmeel is translated in English in Gaster 1899 .

462 Gaster 1899, 206-207.
} 
Amèl-Marduk's imprisonment and his fear that his father might come back to life even after his death. ${ }^{463}$ It is suspicious that these traditions emerge only at a very late date, with both of them aimed at providing the reader with more information about the obscure character of Amēl-Marduk. ${ }^{464}$

When read in light of Leviticus Rabbah and the Chronicle of Jerahmeel, the two cuneiform texts indeed appear to speak of Amēl-Marduk's fall from grace and his pleas to Marduk. However, the texts themselves are very ambiguous in this regard. As von Soden and Schaudig show, the text fragment concerning Amèl-Marduk can be interpreted differently from Finkel's reading. The first part may well be a pejorative description of Amēl-Marduk's rule, but the latter part does not necessarily refer to Amēl-Marduk's reverence for Marduk; instead, it could refer to Nabonidus' veneration. When read without presuppositions, the text does not portray Amēl-Marduk as the victim of a slander campaign. When it comes to the Lament of Nabû-šum-ukīn, the text is an expression of grief and a prayer for deliverance. Reading it as a work of literature, I do not accept that Nabû-šum-ukīn is to be identified with Amēl-Marduk, let alone that the text would reflect a historical event. Therefore, Finkel's thesis on the Babylonian tradition of Amēl-Marduk's captivity is to be rejected ${ }^{465}$ as his reading of the Babylonian literary texts is too strongly guided by much later Jewish traditions, which appear to be narratives aimed at shedding some light on the life of Amēl-Marduk.

The ration lists from the Palace Archive remain the main source for studying Jehoiachin's life in exile. He and his sons were held hostage to ensure the loyalty of Zedekiah and to prepare a new generation of pro-Babylonian vassal kings to rule over Judah. They were maintained by the royal administration, and Jehoiachin was able to live with his family and beget sons in Babylon. The Palace Archive itself is a testimony of Jehoiachin's dependence on the Babylonian administration, and it reminds us that the freedom of the hostages must have been severely limited. They were not restrained by shackles or iron bars, but they were supervised, dependent on their overlords, and not free to leave the city.

The accounts of Jehoiachin's exile in 2 Kings 24 and his amnesty in 2 Kings 25 demonstrate that the authors of these passages were informed of Jehoiachin's deportation to Babylon and his stay there. However, 2 Kgs 25:27-30 paints a grim picture of Jehoiachin's imprisonment, contrasting it with his

463 Leviticus Rabbah xviii:2; Gaster 1899, 207.

464 See Waerzeggers (forthcoming $b$ ).

465 See Waerzeggers (forthcoming b); but cf. Foster 2005, 852; and Oshima 2011, 316-317, who are in favour of Finkel's thesis. 
release and honoured status in the reign of Amēl-Marduk. This narrative appears to describe his past as too gloomy and his future as too bright. The ration lists show that his captivity may be better described as house arrest rather than imprisonment, but it is hard to find any reason why Amēl-Marduk would have accorded him special status in the beginning of his reign. There is no basis to postulate that Jehoiachin first enjoyed royal maintenance and was only later imprisoned. ${ }^{466}$ In the same vein, Becking's theory about Amèl-Marduk's act of amnesty and Finkel's thesis about Jehoiachin's and Amēl-Marduk's common captivity fail to provide a credible historical background for Amēl-Marduk's actions. The last verses of 2 Kings are not a historical remark about Jehoiachin's fate, ${ }^{467}$ but they should be read as literature which yet again uses the motif of an exiled Judean who wins the favour of a foreign king. ${ }^{468}$ The narrative thus provides the reader with some hope after the dark days of exile. ${ }^{469}$

\subsection{Conclusion}

The Palace Archive of Nebuchadnezzar II bears unique evidence of Babylonian deportation practices and the fate of upper-class deportees. Craftsmen, soldiers, officials, and royalty from the border areas of the empire were deported to Babylon in the late seventh and early sixth centuries and maintained by the royal administration. The Palace Archive records oil rations given to people from Iran and the Eastern Mediterranean, who also received at least barley and date beer for their sustenance. It remains unclear whether meat and other more expensive commodities were handed out as well. Be that as it may, deportees were nourished well enough to perform their work, and they were allowed to live with their families and reproduce in exile. This suggests that the deportees were not imprisoned or treated harshly, which would also have damaged their ability to work productively for the state. However, the deportees were supervised and their freedom of movement was severely limited. The ration system itself was an efficient means of control.

The majority of foreigners in the Palace Archive are craftsmen and soldiers who were employed in building projects, crafts, and guarding the city. Some of them may have arrived in Babylon voluntarily, but given their countries of

\footnotetext{
466 Cf. Albertz 2003, 102-104.

467 Noth 1981, 98.

468 Compare to the stories about Daniel, Esther, and Joseph. See Barstad 1996, 28-29 n. 6; Chan 2013, 569-572, the latter with further literature.

469 See, for example, Murray 2001, 264-265; Chan 2013, 572-576; Bodner 2016, 210-212.
} 
origin, most of them were deported as a result of Nabopolassar's and Nebuchadnezzar's campaigns. Also, some members of foreign royalty were taken to Babylon. Royalty from Judah, Ashkelon, and perhaps from Lydia were held captive for two purposes. First, they could be indoctrinated into the values and beliefs of the Babylonian royal house and later sent to rule over the distant vassal states. Second, King Jehoiachin and his sons were held hostage to ensure the loyalty of the vassal king Zedekiah in Jerusalem.

The Palace Archive is famous for its few attestations of King Jehoiachin and his sons as the recipients of oil rations. Their presence in Babylon confirms the biblical account of Jehoiachin's exile at the foreign court, but the narrative of his captivity and amnesty in 2 Kgs 25:27-30 should not be taken at face value: Jehoiachin's severe imprisonment is purposefully contrasted with his release and elevated status at Amēl-Marduk's court, while the final verses of the Book of Kings were intended to offer a ray of hope for those in exile. 